\title{
Welfare assessment of cattle submitted to equestrian sporting events
}

\author{
Avaliação do bem-estar de bovinos submetidos à eventos esportivos equestres \\ Evaluación del bienestar del ganado sometido a eventos deportivos ecuestres
}

Received: 06/22/2021 | Reviewed: 06/30/2021 | Accept: 06/30/2021 | Published: 07/13/2021

Gustavo Rodrigues Queiroz

ORCID: https://orcid.org/0000-0001-8657-5056

Pitágoras Unopar University, Brazil

E-mail: gustavorodriguesqueiroz11@gmail.com

Alexandre Mendes Amude

ORCID: https://orcid.org/0000-0001-7515-7537

Pitágoras Unopar University, Brazil

E-mail: amamude@hotmail.com

Aline Tramontini Zanluchi de Queiroz

ORCID: https://orcid.org/0000-0002-9464-3714

Pitágoras Unopar University, Brazil

E-mail: alinetramontinizanluchi@gmail.com

Sabrina Ribeiro

ORCID: https://orcid.org/0000-0002-9836-1466

Pitágoras Unopar University, Brazil

E-mail: saa-ribeiro@hotmail.com

Francisco Thiago Vieira Oliveira

ORCID: https://orcid.org/0000-0003-3844-5032

Pitágoras Unopar University, Brazil

E-mail: fthiagooliveira@hotmail.com

Kemily Tamires Teodoro de Oliveira

ORCID: https://orcid.org/0000-0002-7968-7786

Pitágoras Unopar University, Brazil

E-mail: kemily.tamires@gmail.com

Maria Carolina Ricciardi Sbizera

ORCID: https://orcid.org/0000-0001-9122-1949

Pitágoras Unopar University, Brazil

E-mail: mcrsbizera@gmail.com

Marivaldo da Silva Oliveira

ORCID: https://orcid.org/0000-0002-2242-2111 Pitágoras Unopar University, Brazil

E-mail: marivaldodeoliveira@hotmail.com

Marta Juliane Gasparini

ORCID: https://orcid.org/0000-0001-8896-942X Pitágoras Unopar University, Brazil E-mail: martajuliane@hotmail.com

Marcelo Diniz dos Santos

ORCID: https://orcid.org/0000-0002-5486-8353 Pitágoras Unopar University, Brazil

E-mail: marcelo.diniz@kroton.com.br

Fabíola Cristine de Almeida Rego

ORCID: https://orcid.org/0000-0003-4516-7632 Pitágoras Unopar University, Brazil

E-mail: fabiola.cristine@kroton.com.br

Luiz Fernando Coelho da Cunha Filho

ORCID: https://orcid.org/0000-0003-1286-9101 Pitágoras Unopar University, Brazil

E-mail: vtluiz.cunha@gmail.com

\begin{abstract}
The concern with the animal's welfare has become increasingly frequent and the use of cattle in sporting events has aroused discussions about the preservation and integrity of these animals. The objective of this work was to evaluate whether the cattle participating in the team roping modality receive all support regarding the animal welfare criteria. During the 41st National Championship of the Quarter Horse Breed of Work and Conformation, aspects of animal welfare of 410 cattle that participated in the team roping were evaluated. Behavioral aspects were observed before, during and after the end of the competition, in addition to quantifying the number of runs per animal, the presence of ectoparasites, thermal comfort, food and hydration. It was possible to conclude that the environment in which the tests were carried out, the feeding conditions, the space and the thermal comfort meet the criteria of animal welfare.
\end{abstract}


Keywords: Equestrian sport; Team roping; Calf; Thermography.

\section{Resumo}

A preocupação com o bem-estar dos animais tem se tornado cada vez mais frequente e a utilização de bovinos em provas esportivas tem despertado discussões a respeito da preservação e integridade destes animais. O objetivo deste trabalho foi avaliar se os bovinos participantes da modalidade de laço em dupla recebem todo suporte quanto aos critérios de bem-estar animal. Durante a realização do $41^{\circ}$ Campeonato Nacional da Raça Quarto de Milha de Trabalho e Conformação, foi avaliado aspectos do bem-estar animal de 410 bovinos que participaram das provas de laço em dupla. Foram observados aspectos comportamentais antes, durante e após o término da competição, além de quantificar o número de corridas por animal, presença de ectoparasitas, conforto térmico, alimentação e hidratação. Foi possível concluir que o ambiente em que foram realizadas as provas, as condições de alimentação, o espaço e o conforto térmico atendem os critérios de bem-estar animal.

Palavras-chave: Esporte equestre; Laço em dupla; Garrotes; Termografia.

\section{Resumen}

La preocupación por el bienestar animal se ha vuelto cada vez más frecuente y el uso de ganado en competiciones deportivas ha suscitado discusiones sobre la preservación e integridad de estos animales. El objetivo de este trabajo fue evaluar si los bovinos que participan en la modalidad de doble empalme reciben pleno apoyo en cuanto a los criterios de bienestar animal. Durante el $41^{\circ}$ Campeonato Nacional de la Carrera de Caballos Cuarto de Milla para el Trabajo y la Conformación se evaluaron aspectos del bienestar animal de 410 bovinos que participaron en las carreras de doble lazo. Se observaron aspectos de comportamiento antes, durante y después del final de la competencia, además de cuantificar el número de carreras por animal, presencia de ectoparásitos, confort térmico, alimentación e hidratación. Se pudo concluir que el entorno en el que se realizaron las pruebas, las condiciones de alimentación, el espacio y el confort térmico cumplen con los criterios de bienestar animal.

Palabras clave: Deporte ecuestre; Laço em dupla; Garrotes; Termografía.

\section{Introduction}

Whenever animals are involved in any activities, including animal production or sports events, animal welfare practices must be present (Fawcett et al., 2019). Nevertheless, the role of veterinarians in the defense and education of the public on the welfare of animals used in sport and recreations deserves further discussion (Fawcett et al., 2019; Rizzuto et al., 2020).

The team roping is a competitive sport where two riders aim to tie a calf in the shortest time possible, the first roper tie the animal by the head and the second by the feet, in less than 60 seconds The modality emerged in the United States, mimetizing the management of animals on farms, with the daily routine to the field, sometimes it is necessary to capture the calves to provide management, and it was due to the competitiveness among workers that the activity would have become a sport (ABQM, 2020).

The team roping is considered a cultural manifestation in Brazil, and on May 30, 2017, the proposed amendment to the constitution (PEC 304) was approved, adding paragraph 7 to art. 225 of the Federal Constitution, to determine that sports practices that use animals are not considered ill-treatment (Brasil, 2017).

In the literature it is possible to find several articles that address the participation of animals in the modality of team roping, however, focused almost exclusively on the impact of the tests on horses (Dabareiner et al., 2005; Pereira et al., 2018; Gerardi et al., 2019). It was then felt the need to understand more about the subject in cattle that are also indispensable members for these tests to occur. Although studies point out that there are no cervical lesions caused in cattle due to the practice of equestrian sports (Pellegrini et al., 2017).

The objective of this work was to evaluate whether the cattle participating in the team roping competition during the 41st National Championship of the Quarter Horse Breed of Work and Conformation received full support regarding the criteria and concepts of animal welfare.

\section{Methodology}

The present study was authorized by the ethics committee for the use of animals (CEUA) of The Pythagoras Unopar University, under protocol number 029/18. 
The study was carried out during the 41st National Championship of the Quarter Horse Breed of Work and Conformation, in the municipality of Londrina, State of Paraná, Brazil. Physical aspects of well-being were evaluated, of 410 cattle between 13 and 18 months of age, submitted to team roping championship.

The animals were identified by ink numbering in the lumbar region so that observers could quantify the number of runs per animal on the same day. During the evaluation, behavioral aspects were observed before, during and after the participation of the animals in the test, as well as the performance of clinical examination before starting the test and after and last run, including the evaluation of body score and presence of ectoparasites.

The body condition score of all animals was evaluated by the methodology proposed by Nicholson and Butterworth (1986).

For behavioral evaluation before and during the test, four observers were required, two of which were located at the place of exit of the animals, observing their behavior before the run and two in the stands observing their behavior during the run. In addition, the behavioral observation of the animals is performed in the waiting cattle shed, where the stocking rate, the bed, feeder and drinking conditions were analyzed, in addition to thermal comfort.

Lameness evaluations were identified at the arrival and exit of the animals from the test site, as well as thermography exams were performed to observe whether the cattle were in thermal comfort.

After the test, the animals' behavior was observed in relation to the interaction with the environment, feeding, rumination and water intake. In the final clinical examination observer if the possible complications that could occur during the competition due to their nature. Therefore, five observers were needed to evaluate the presence of alterations such as ocular lesions, lesions in horns and ears, lameness, and body score along with the presence of ectoparasites and degree of hydration.

The degree of lameness was established as according to Greenough \& Weaver (1997), as follows: classification 1 for normal locomotion, classification 2 for slight lameness and the classification 3 for moderate lameness, classification 4 for severe lameness and classification 5 for functional impotence.

The fluorescein test was used in the diagnosis and evaluation of the extent of corneal lesions and to identify small epithelial defects. To this end, the fluorescein test was used using $1 \%$ sodium fluorescein ophthalmic solution, applied directly to the cornea of the animals. Fluorescein is a water-soluble dye that, in the presence of corneal ulcer, can impregnate corneal extroma in places where intercellular junctions break, blushing it with bright green.

The identification of dehydrated animals was performed by the presence of endophthalmia and evaluation of skin turgor. Also, blood collection was performed to verify hydration of 40 garrotes through hematocrit, for which water was offered with oral electrolyte powder (ELETROEQUI, Organnact,Brazil) ad libitum.

Even though the animals that were submitted to the test mandatorily used the headguards, the horn and ear injuries were evaluated, and all the animals were examined before the first run and just after the last run, that is, in the placement of the protectors and in the removal as well.

Ectoparasites were also observed throughout the right half of the animals, neck, abdominal and dorsal region.

The animals did not remain in the championship place full-time, at the end of the day they returned to a property located 15 kilometers from the site of the championship, where they were in 12 pickets of Cynodon spp grass.

All information was annotated in form, and then transferred to Excel 2010 spreadsheet. For descriptive analysis of the data obtained.

\section{Results and Discussion}

During the study, it was observed that the stocking rate of the cattle shed was adequate, being $4 \mathrm{~m}^{2} /$ animal. According to Burgi and Pires (2010), the shed for storage of cattle to perform zootechnical procedures, it is recommended at least 
$1.0 \mathrm{~m}^{2} /$ animal, so during this event, the animals were opportunistic to 4 times more space, avoiding the need for animals to compete for space, providing comfort and tranquility to the animals used during the team roping championship. It is emphasized that the cattle sheds were composed of bed of oat straw and considered a ventilated and shaded environment as shown in Figure 1. The feeding was adequate during this period with supply of Cynodon spp hay (coast-cross), a bulky food of good nutritional quality (Resende et al., 2017).

Thermography has been widely used to evaluate the thermal stress of animals over the years. This biotechnology has been effective because it is a non-invasive method, without direct contact with the skin of animals and that does not emit ionizing radiation, besides enabling the evaluation of an isolated animal or group, in real time and under relative distance (Chacur et al., 2016). The gain or heat loss is influenced by the size of the animal, so, these factors are higher demonstrated in adult animals, with this it is possible to evaluate the temperature of young animals, considering that the temperature will be higher when compared to adult cattle (Navarini, et al., 2009). Figure 1 shows that the body temperature found is $37.2^{\circ} \mathrm{C}$ demonstrating that the animal were in balance with the environment.

Figure 1. Thermography demonstrating the temperature of the environment and animals at 18 o'clock in the afternoon, evidencing the thermal comfort of cattle submitted to team roping, during the 41st National Championship of the Quarter Horse Breed of Work and Conformation, in the municipality of Londrina, State of Paraná, Brazil.
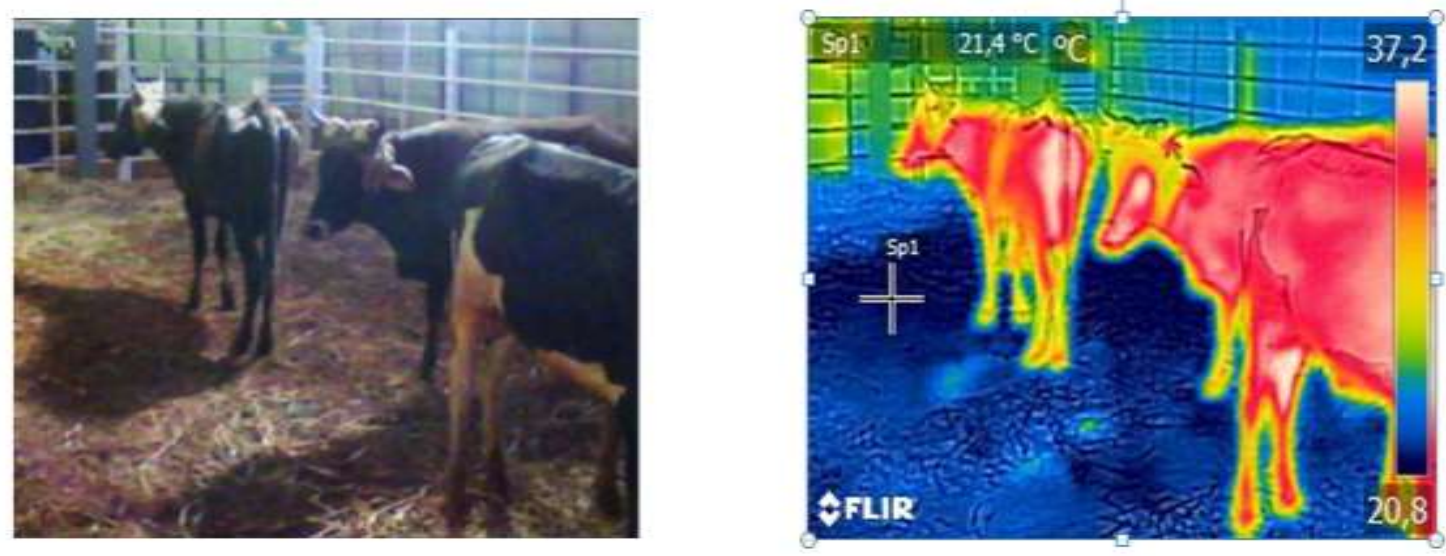

Source: Authors.

The assessment of the environment in which the animals were housed indicates that the conditions have been offered to promote the welfare of the cattle involved, which was evidenced by the expression of natural behaviour of the animals, as food and water intake, adequate rumination, besides being observed from the very well-set and quiet animals, and some on them even in sternal recumbency and others stand still, going according to the recommended for the species (Bond et al., 2012).

It is emphasized that between the days, there was the maintenance of the cattle shed, with change of bed and removal of waste. This factor made animal welfare considerably possible, since it promoted a clean and comfortable environment so that the animals could feed and remain at rest, respecting the concepts established by Braga et al., (2018) for intensive animal grouping.

During the three days of the event, the team roping competition promoted 1043 runs, with an average of 16 seconds of each run, and of the 410 cattle that participated in the run and were thoroughly evaluated, 100\% (410 in 1043 runs) did not present injuries in horns and ears, thus demonstrating the effectiveness of the protective equipment used during the championship.

Fluorescein is used to diagnose eye ulcers in cattle (Andrade, et al 2008). During the present study, none of the animals presented corneal ulcer, so, it can be affirmed that no head loop and the rope did not cause ocular trauma in the cattle. 
On the initial and final clinical examination, no bovine presented lameness when evaluated in free locomotion by the methodology proposed by Greenough and Weaver (1997), that is, the act of tying the legs of the animal did not cause any alteration of the pattern of locomotion of the animals, since none manifested pain.

In the evaluation of the physical status of the animals, most of them had regular body conditions for sports practice, with an average body score of 2.5 points (on a scale of 1 to 5 points), however, 39 animals had inappropriate conditions for the sport (body condition of 1.5 points), and were therefore prevented from competing, returning to the place of origin.

It was possible to observe that 12 animals (2.92\%) presented mild degree of dehydration upon arrival at the competition place, characterized by the presence of increased turgor of the neck skin, from 2 to 3 seconds, characterizing mild dehydration (Hall, 2011), but that at the end of the day were restored by the ingestion of water with oral electrolytic moisturizer.

In Table 1 we have the demonstration of the number of runs promoted on each day of competition, how many animals participated in them. Table 1 shows the average runs per animal each day.

Table 1. Number of animals on each day of double tie run, during the 41st National Championship of the Quarter Horse Breed of Work and Conformation that took place in Londrina, Parana State, Brazil, July 14 and 22, 2018.

\begin{tabular}{cccc}
\hline & D1 & D2 & D3 \\
\hline Number of runs & 317 & 218 & 508 \\
Number of animals that ran & 128 & 116 & 166 \\
Average runs/animal & 2.48 & 1.88 & 3.06 \\
\hline
\end{tabular}

* D1: first day of competition; D2: second day of competition; D3: third day of competition. Source: Authors.

The average of runs per garrote ranged from 1.88 to 3.06, therefore a low number of runs, remembering that the number of runs is related to the number of pairs of riders participating. With this result, it is possible to affirm that the animals did not participate in the event exhaustively, as recommended by the Manual of Good Practices for cattle participating in equestrian sports activities (Silva Filho et al., 2020), which may also have contributed to the null index of lameness observed in the present study, indicating that there are no skeletal muscle injuries resulting from the act of tying the limbs of the animals during the team roping.

Regarding the behavior of the animals during the period of stay in the championship place, it was observed that the cattle were in a comfortable management area, shaded, with adequate bed, feeding in appropriate troughs, in adequate space. The management team was very efficient in the conduction of the animals, using flags and always in silence to avoid the stress of the animals.

\section{Conclusion}

The environment in which the team roping equestrian championship was performed, the feeding conditions of the cattle, the physical space, protective devices and thermal comfort were adequate for animal welfare.

\section{References}

ABQM (2015) Regulamento do Bem-Estar Animal em Competições, da Associação Brasileira de Criadores de Cavalo Quarto de Milha. https://www.abqm.com.br

ABQM. (20 Regulamento Geral de Concursos e Competições da Raça Quarto de Milha. https://www.abqm.com.br 
Andrade, A. L. (2008) Semiologia do Sistema Visual dos Animais Domésticos. In: Feitosa, F.L.F. Semiologia Veterinária: A Arte do Diagnóstico. Roca, 2008. Cap. 14, p. 644.

Bond, G. B., Almeida, R. D., Ostrensky, A., \& Molento, C. F. M. (2012). Métodos de diagnóstico e pontos críticos de bem-estar de bovinos leiteiros. Ciência Rural, 42(7), 1286-1293.

Braga, J., Macitelli, F., de Lima, V. A., \& Diesel, T. (2018). O modelo dos "Cinco Domínios" do bem-estar animal aplicado em sistemas intensivos de produção de bovinos, suínos e aves. Revista Brasileira de Zoociências, 19(2), 1-10.

Brasil (2017) Legislação Federal. Art. 225, emenda constitucional n 96. Práticas desportivas que utilizem animais não são consideradas cruéis, nas condições que especifica.

Burgi, R. \& Pires, A. V. (2010). Instalações para bovinos de corte. In: Pires, A.V. (Org). Bovinocultura de Corte. FEALQ, 1(6), 89-126.

Chacur, M. G. M., Souza, C. D., Andrade, I. B., Pepino, G., Bastos, F. L. G. D., Souza, M. G. R., \& Marques Jr, A. D. P. (2016). Aplicações da termografia por infravermelho na reprodução animal e bem-estar em animais domésticos e silvestres. Revista Brasileira de Reprodução Animal, 40(3), 88-94.

Dabareiner, R. M., Cohen, N. D., Carter, G. K., Nunn, S., \& Moyer, W. (2005). Lameness and poor performance in horses used for team roping: 118 cases. Journal of American Veterinary Medical Association, 226(10), 1694-1699.

Fawcett, A., Hazel, S., Collins, T., Degeling, C., Fisher, A., Freire, R., Hood, J., Johnson, J., Lloyd, J., Phillips, C., Stafford, K., Tzioumis, V., McGreevy, P. (2019). Australian and New Zealand Veterinary Students' Opinions on Animal Welfare and Ethical Issues Concerning Animal Use within Sport, Recreation, and Display. Journal of Veterinary Medical Education, 46(2), 264-272.

Gerardi, B., Denadai, D. S., Pereira, M. S., Chaves, A. A., Barbosa, J. P. B., Peiró, R. J., Feitosa, F. L. F., \& Mendes, L. C. N. (2019). Use of infrared thermography in Quarter Horse submitted to team roping. Pesquisa Veterinária Brasileira, 39(7), 530-537.

Greenough, p. R. \& weaver, a. D. (2011) Lameness in cattle. (3a ed.), Saunders, 336.

Hall, J. E. Tratado de fisiologia médica. (12a ed.), Elsevier; 2011.

Navarini, F. C., Klosowski, E. S., Campos, A. T., Teixeira, R. D. A., \& Almeida, C. P. (2009). Conforto térmico de bovinos da raça nelore a pasto sob diferentes condições de sombreamento e a pleno sol. Engenharia Agrícola, 29(4), 508-517.

Nicholson, M. J., \& Butterworth, M. H. (1986). A guide to condition scoring of zebu cattle. Addis Ababa: International Livestock Centre for Africa, 29.

Pellegrini, M. M., Pellegrini, C. M., Gallo, M. A., Foz Filho, R. D. P., \& Zoppa, L. D. V. (2017) Avaliação radiográfica da coluna cervical de bovinos que participaram de prova de laço em duplas. PUBVET, 11(6), 538-645.

Pereira, M. S., Gerardi, B., Denadai, D. S., Chaves, A. A., Barbosa, J. P. B., Lina, J. E. O. Z., Gomide, M. W., \& Mendes, L. C. N. (2018) Avaliação da lactatemia e das enzimas musculares de equinos Quarto de Milha submetidos à prova de laço em dupla com diferentes tipos de treinamento. Pesquisa Veterinária Brasileira, $38(9), 1856-1862$

Resende, H., Leite, J., de Resende, J. C., \& Carvalho, L. D. A. (2017). Tecnologia e Custo do Feno de Coast-cross. Embrapa Gado de Leite-Comunicado Técnico (INFOTECA-E).

Rizzuto, S., Evans, D., Wilson, B., \& McGreevy, P. (2020) Exploring the Use of a Qualitative Behavioural Assessment Approach to Assess Emotional State of Calves in Rodeos. Animals, 10(1), 113.

Silva Filho, O. C. (2020). Manual de boas práticas para bovinos participantes de atividades esportivas equestres. Associação Brasileira de Criadores de Cavalos Quarto de Milha, 46. 